\title{
Synthesis and Properties of Diazopiperidiones for use in Non-Chemically Amplified Deep UV Photoresists
}

\author{
Peter I. Tattersall, David Breslin, Scott M. Grayson, Bill Heath, \\ Kathleen Lou, Christopher L. Mc Adams, Dennis McKean, * \\ Benjamen M. Rathsack, and C. Grant Willson.
}

\section{Supplementary Data}

Experimental Section. ${ }^{1} \mathrm{H}$ NMR spectra were run at $300 \mathrm{MHz}$ and ${ }^{13} \mathrm{C} \mathrm{NMR}$ at $75 \mathrm{MHz}$ in $\mathrm{CDCl}_{3}$ on a General Electric GE-300 spectrometer unless otherwise stated. Mass spectra (MS) were obtained on a VG ZAB2-E mass spectrometer using either chemical ionization (CI) or fast atom bombardment (FAB). Melting points are uncorrected. IR were carried out using a Nicolet Magna - IR 550 spectrometer. Elemental analysis were performed by Atlantic Microlab, Incorporated, Norcross, GA. Ultraviolet-visible absorption spectra (UV-VIS) were recorded on a Varian Cary-1 spectrophotometer. All reactions were carried out under an $\mathrm{N}_{2}$ atmosphere unless otherwise stated.

Solvents and Reagents. Tetrahydrofuran (THF) was distilled from sodium and benzophenone. DCM was distilled form calcium hydride. Triethylamine and Nmethylmorpholine were dried over 3 Á molecular sieves. Ethanol was dried over calcium 
sulfate overnight prior to use. Column chromatography was carried out on Merck silica gel 60. All other reagents were commercially available (Aldrich) and used as received.

\section{Synthetic procedure for the butyl functionalized model compound:}

$N$-Butyl-(methyl-2-aminopropanoate), 6. A solution of methyl acrylate, (11.8 g, 0.137

mol) in methanol $(30 \mathrm{~mL})$ was added over a period of $30 \mathrm{~min}$ to a solution of butylamine $(10 \mathrm{~g}, 0.137 \mathrm{~mol})$ in methanol $(100 \mathrm{~mL})$ in at $0^{\circ} \mathrm{C}$. The solution was allowed to stir for $4 \mathrm{~h}$ before being distilled under reduced pressure. The title product was obtained as a colorless oil, (13.75 g, 63\%), between $105-106^{\circ} \mathrm{C}$ at $22 \mathrm{~mm} \mathrm{Hg}$. IR (film): 2956, 2929, 1740, $1463 \mathrm{~cm}^{-1} ;{ }^{1} \mathrm{H}$ NMR (300 MHz, $\left.\mathrm{CDCl}_{3}\right): 3.68(\mathrm{~s}, 3 \mathrm{H}), 3.48(\mathrm{t}, \mathrm{J}=5.1,2 \mathrm{H}), 3.35(\mathrm{~s}$, $3 \mathrm{H}), 2.91(\mathrm{t}, \mathrm{J}=6.7,2 \mathrm{H}), 2.79(\mathrm{t}, 2 \mathrm{H}, \mathrm{J}=5.2), 2.52(\mathrm{t}, \mathrm{J}=6.7,2 \mathrm{H}), 1.70(\mathrm{~s}, 1 \mathrm{H}) ;{ }^{13} \mathrm{C}$ NMR (75 MHz, $\left.\mathrm{CDCl}_{3}\right): 34.4,44.9,48.9,51.3,58.5,71.7,172.9 ;$ LRMS (CI) m/z (rel. intensity): 160 (M+1, 100); HRMS (CI): $\mathrm{m} / \mathrm{z}$ calcd. for $\mathrm{C}_{8} \mathrm{H}_{18} \mathrm{NO}_{2}(\mathrm{M}+1) 160.13375$ found 160.13339; Anal. Calcd. for $\mathrm{C}_{8} \mathrm{H}_{17} \mathrm{NO}_{2}$ : C, 60.3; H, 10.69; N, 8.80. Found C, 59.9; H, 10.86; N, 8.33.

$N$-Butyl- $N$-(methylmaonyl)-methyl-2-aminopropanoate, $7 . N$-Butyl-(methyl-2aminopropanoate), $(6.0 \mathrm{~g}, 0.0377 \mathrm{~mol})$ and dimethyl malonate, $(30 \mathrm{~mL})$ were mixed together and heated at reflux for 2-3 $\mathrm{h}$. The reaction turned orange in color. The mixture was allowed to cool before the excess dimethyl malonate was removed by distillation under reduced pressure (1-2mm). The product was obtained as an orange oil, $(9.6 \mathrm{~g}$, 99\%), which was used without any further purification. IR (evap.film): 2957, 1735, 1652, $1437 \mathrm{~cm}^{-1} ;{ }^{1} \mathrm{H}$ NMR $\left(300 \mathrm{MHz}, \mathrm{CDCl}_{3}\right): 3.74(\mathrm{~s}, 3 \mathrm{H}), 3.38-3.70(\mathrm{~m}, 7 \mathrm{H}), 3.16-3.27$ (m, $2 \mathrm{H}), 2.51-2.58(\mathrm{~m}, 2 \mathrm{H}), 1.39-1.42(\mathrm{~m}, 2 \mathrm{H}), 1.20-1.35(\mathrm{~m}, 2 \mathrm{H}), 0.87(\mathrm{~s}, 3 \mathrm{H}) ;{ }^{13} \mathrm{C}$ NMR $(75$ 
$\left.\mathrm{MHz}, \mathrm{CDCl}_{3}\right): 13.6,19.8,29.3,31.0,32.2,33.2,40.9,42.4,43.7,45.2,49.1,51.5,52.2$, 165.7, 167.9, 172.3; LRMS (CI) m/z (rel. intensity): 260 (M+1, 100); HRMS (CI): m/z calcd. for $\mathrm{C}_{12} \mathrm{H}_{22} \mathrm{NO}_{5}(\mathrm{M}+1) 260.14896$ found 260.14980; Anal. Calcd. for $\mathrm{C}_{12} \mathrm{H}_{21} \mathrm{NO}_{5}$ : C, 55.5; H, 8.10; N, 5.40. Found C, 54.5; H, 7.86; N, 5.11.

$N$-Butyl-3-carboxyethyl-2,4-dioxo-piperidine, 8. A solution of $N$-butyl- $N$ (methylmaonyl)-methyl-2-aminopropanoate, $(9.37 \mathrm{~g}, 0.0362 \mathrm{~mol})$ in dried toluene (40 $\mathrm{mL}$ ) was added, over a period of $1 \mathrm{~h}$, to a mixture of potassium carbonate, $(24.7 \mathrm{~g}, 0.179$ $\mathrm{mol})$ and 18 -crown- 6 ether $(0.88 \mathrm{~g}, 0.0033 \mathrm{~mol})$ in toluene, $(60 \mathrm{~mL})$ at reflux. The mixture was heated at reflux for a further $7 \mathrm{~h}$ before being worked up. The material was cooled and poured into a separating funnel. The flask was washed with water, $(3 \times 50$ $\mathrm{mL}$ ) and this was transferred into the funnel. The funnel was swirled rather than shaken to avoid the formation of an emulsion. The aqueous phase was separated and the organic phase washed with water $(2 \times 100 \mathrm{~mL})$. The aqueous phase was chilled in an ice bath and stirred with dichloromethane $(100 \mathrm{~mL})$. The basic solution was acidified to $\mathrm{pH} 1$ with $6 \mathrm{~N}$ $\mathrm{HCl}$ solution and separated immediately. The aqueous phase was saturated with brine and extracted with dichloromethane $(2 \times 100 \mathrm{~mL})$. The combined organic phase was dried $\left(\mathrm{MgSO}_{4}\right)$ and evaporated in vacuo to give an orange oil, $(7.38 \mathrm{~g}, 90 \%)$ which was used without any further purification. IR (film): 2957, 2873, 1734, 1653, $\mathrm{cm}^{-1} ;{ }^{1} \mathrm{H}$ NMR (300 $\left.\mathrm{MHz}, \mathrm{CDCl}_{3}\right): 3.75(\mathrm{~s}, 3 \mathrm{H}), 3.51(\mathrm{~s}, 1 \mathrm{H}), 3.22-3.36(\mathrm{~m}, 6 \mathrm{H}), 2.43-2.58(\mathrm{~m}, 2 \mathrm{H}), 1.31-2.30$ (m, 2H), 1.06-1.24 (m, 2H), 0.79 (t, $J=7.3,3 \mathrm{H} \quad$ );. LRMS (CI) m/z (rel. intensity): 170 (100), $184(35), 196(50), 228(\mathrm{M}+1,30) \mathrm{HRMS}(\mathrm{CI}) \mathrm{m} / \mathrm{z}$ calcd. for $\mathrm{C}_{11} \mathrm{H}_{17} \mathrm{NO}_{4}(\mathrm{M}+1)$ 228.12441 found 228.12358; Anal. Calcd. for $\mathrm{C}_{11} \mathrm{H}_{17} \mathrm{NO}_{4}$ : C, 57.6; H, 7.49; N, 6.11. Found C, 57.3; H, 7.63; N, 5.99. 
$N$-Butyl-2,4-piperidione, 9. A solution of $N$-butyl-3-carboxyethyl-2,4-dioxo-piperidine, $(6.45 \mathrm{~g}, 0.0284 \mathrm{~mol})$ in acetonitrile, $(60 \mathrm{~mL})$ and water, $(1 \mathrm{~mL})$ was heated at reflux for 2 h. The solvents were evaporated in vacuo and the residue was distilled to give the product as an oil, (3.1 g, 65\%), (130-132 ${ }^{\circ} \mathrm{C}$ at $\left.1 \mathrm{~mm} \mathrm{Hg}\right)$. IR (film): 2958, 2932, 2873 1730, 1646 $\mathrm{cm}^{-1} ;{ }^{1} \mathrm{H}$ NMR $\left(300 \mathrm{MHz}, \mathrm{CDCl}_{3}\right): 3.47(\mathrm{t}, J=6.2,2 \mathrm{H}), 3.49(\mathrm{t}, J=7.5,2 \mathrm{H}), 3.21(\mathrm{~s}$, $2 \mathrm{H}), 2.49(\mathrm{t}, J=6.2,2 \mathrm{H}), 1.39-1.46(\mathrm{~m}, 2 \mathrm{H}), 1.17-1.25(\mathrm{~m}, 2 \mathrm{H}), 0.82(\mathrm{t}, J=7.2,3 \mathrm{H})$; ${ }^{13} \mathrm{C}$ NMR (75 MHz, $\left.\mathrm{CDCl}_{3}\right)$ 13.6, 19.8, 29.4, 38.4, 43.0, 46.6, 48.8, 165.7, 203.5; HRMS (CI) m/z (rel. intensity): $170(\mathrm{M}+1,100), 140$ (10); HRMS (CI): m/z calcd. for $\mathrm{C}_{9} \mathrm{H}_{16} \mathrm{NO}_{2}$ $(\mathrm{M}+1) 170.11810$ found 170.11813; Anal. Calcd. for $\mathrm{C}_{9} \mathrm{H}_{15} \mathrm{NO}_{2}$ : C, 63.9; $\mathrm{H}, 8.87 ; \mathrm{N}$, 8.28. Found C, 61.6; H, 8.75; N, 7.63.

p-Toluenesulfonyl azide. A solution of sodium azide ( $6.92 \mathrm{~g}, 0.110 \mathrm{~mol})$ in water (24 $\mathrm{mL})$ was added ethanol $(36 \mathrm{~mL})(99+\%)$. To this solution was added a warmed solution of $p$-toluenesulfonyl chloride $(18.0 \mathrm{~g}, 0.103 \mathrm{~mol})$ in ethanol $(100 \mathrm{~mL})(99+\%)$. During the addition sodium chloride separated to give a precipitate off white in color. The reaction mixture was stirred at room temperature overnight. The solvent was evaporated in vacuo and the residue mixed with water $(100 \mathrm{~mL})$ in a separatory funnel. The oil layer was separated and washed with water. The oil was dried $\left(\mathrm{Na}_{2} \mathrm{SO}_{4}\right)$. After filtration this gave title compound as a colorless oil (16.4 g, 82\%). ' ${ }^{1} \mathrm{H}$ NMR (300 MHz, DMSO$\left.\mathrm{d}_{6}\right) 7.92(\mathrm{~d}, 2 \mathrm{H}), 7.55$ (d, 2H), 2.46 (s, 3H); ${ }^{13} \mathrm{C}$ NMR: 146.5, 134.5, 130.6, 127.3, 21.1; IR (evap. film): $v_{\max } 3067,2980,2924,2126,1371,1190,1167,662,593,539$. 
$N$-Butyl-3-diazo-2,4-dioxo-piperidine, 10. To a solution of $N$-butyl-2,4-piperidione, $(2.0 \mathrm{~g}, 0.0118 \mathrm{~mol})$ in acetonitrile, $(25 \mathrm{~mL})$ at $0^{\circ} \mathrm{C}$ was added dried toluenesulfonyl azide, (2.65 g, $0.0124 \mathrm{~mol})$ and $\mathrm{N}$-methyl morpholine, $(2.65 \mathrm{~g}, 0.0308 \mathrm{~mol})$. After $1.5 \mathrm{~h}$ at $0^{\circ} \mathrm{C}$ the solvents were evaporated in vacuo and the residue was dissolved in chloroform, (70 $\mathrm{mL}$ ) and washed quickly with cold $0.5 \mathrm{M} \mathrm{NaOH}$ solution $(100 \mathrm{~mL})$. The organic phase was dried, $\left(\mathrm{MgSO}_{4}\right)$ and evaporated in vacuo to yield a pale red oil. Purification by flash column chromatography eluting with 2:1 hexanes:ethyl acetate gave the product as a colorless oil, (1.95 g, 85\%). IR (film): 2959, 2932, 2873, 2134, 1669, $1635 \mathrm{~cm}^{-1} ;{ }^{1} \mathrm{H}$ $\operatorname{NMR}\left(300 \mathrm{MHz}, \mathrm{CDCl}_{3}\right): 3.35-3.41(\mathrm{~m}, 4 \mathrm{H}), 2.54(\mathrm{t}, J=6.4,2 \mathrm{H}), 1.41-1.49(\mathrm{~m}, 2 \mathrm{H})$, $1.18-1.31(\mathrm{~m}, 2 \mathrm{H}), 0.85(\mathrm{t}, J=7.2,2 \mathrm{H}) ;{ }^{13} \mathrm{C} \mathrm{NMR}\left(75 \mathrm{MHz}, \mathrm{CDCl}_{3}\right)$ 13.6, 19.8, 29.6, 36.4, 42.6, 46.7, 60.1, 160.0, 187.8; HRMS (CI) m/z (rel. intensity): 196 (M+1, 100), HRMS (CI): m/z calcd. for $\mathrm{C}_{9} \mathrm{H}_{14} \mathrm{~N}_{3} \mathrm{O}_{2}(\mathrm{M}+1) 196.10860$ found 196.10755; Anal. Calcd. for $\mathrm{C}_{9} \mathrm{H}_{13} \mathrm{~N}_{3} \mathrm{O}_{2}:$ C, 55.3; H, 6.67; N, 21.5. Found C, 54.9; H, 6.85; N, 21.3.

\section{Synthetic procedure for dissolution inhibitor candidate 21}

4,8-Bis(toluenesulfonyloxymethyl)tricyclo[5.2.1.0 $\left.{ }^{2,6}\right]$ decane. 4,8-Bis(hydroxymethyl)

tricyclo $\left[5 \cdot 2 \cdot 1.0^{2,6}\right]$ decane (mixture of isomers) was dried prior to use by azeotroping with toluene. A solution of triethylamine $(28.5 \mathrm{~mL}, 0.205 \mathrm{~mol})$ and $(18.25 \mathrm{~g}, 0.0930 \mathrm{~mol})$ in anhydrous THF $(50 \mathrm{~mL})$ was stirred at room temperature for $30 \mathrm{~min}$. To this, a solution of tosylchloride ( $35.45 \mathrm{~g}, 0.186 \mathrm{~mol})$ in THF $(100 \mathrm{~mL})$ was added dropwise over a 30 min period. The reaction mixture was stirred at room temperature overnight. The white precipitate was removed by filtration and the solvent was evaporated in vacuo to give the desired product, which was used without further purification. IR (film): 2951, 1361, 
1175, 1189, 953, 814, 665, $572 \mathrm{~cm}^{-1} ;{ }^{1} \mathrm{H}$ NMR (300 MHz, $\left.\mathrm{CDCl}_{3}\right): 0.78-1.86(\mathrm{~m}), 2.39$ (s, $3 \mathrm{H}), 3.06(\mathrm{~m}), 3.70(\mathrm{~m}), 7.29$ (d, $2 \mathrm{H}, J$ 8.1), 7.72 (d, $2 \mathrm{H}, J$ 8.2); HRMS (CI): m/z calcd. for $\mathrm{C}_{26} \mathrm{H}_{33} \mathrm{O}_{6} \mathrm{~S}_{2}\left(\mathrm{M}+\mathrm{H}^{+}\right)$505.1719, found 505.1717.

4,8-Bis(bromomethyl) tricyclo[5.2.1.0 $\left.{ }^{2,6}\right]$ decane, 11. To a solution of the BHD bistosylate, $(14.35 \mathrm{~g}, 0.0285 \mathrm{~mol})$ in acetone, $(150 \mathrm{~mL})$ (dried over potassium carbonate) was added lithium bromide, $(14.8 \mathrm{~g}, 0.171 \mathrm{~mol})$ and the mixture heated at reflux overnight. A solid formed which was removed by filtration and the solvent was evaporated in vacuo. The residue was taken up in diethyl ether and washed with water and brine. The organic phase was dried $\left(\mathrm{MgSO}_{4}\right)$ and the solvent evaporated in vacuo. Purification by dry flash chromatography eluting with hexanes gave the desired product as a clear colorless oil, $\left(4.51 \mathrm{~g}, 49 \%\right.$ ). IR (film): 2950, 2873, 1244, $639 \mathrm{~cm}^{-1}$; ${ }^{1} \mathrm{H}$ NMR $\left(300 \mathrm{MHz}, \mathrm{CDCl}_{3}\right): 0.9-2.5(\mathrm{~m}, 14 \mathrm{H}), 3.0-3.8(\mathrm{~m}, 4 \mathrm{H}) ;{ }^{13} \mathrm{C} \mathrm{NMR}\left(75 \mathrm{MHz}, \mathrm{CDCl}_{3}\right): 30-$ 55 (all signals); LRMS (CI) m/z (rel. intensity) 323 (45), 321 (100), 319 (55); HRMS (CI): $\mathrm{m} / \mathrm{z}$ calcd. for $\mathrm{C}_{12} \mathrm{H}_{18} \mathrm{Br}_{2}\left(\mathrm{M}+\mathrm{H}^{+}\right)$318.9698, found 318.9697. Anal. Calcd. for $\mathrm{C}_{12} \mathrm{H}_{18} \mathrm{Br}_{2}$ : C, 46.15; H, 5.77. Found C, 45.83; H, 5.78.

4,8-Bis(benzylmethylthioether) tricyclo[5.2.1.0 $\left.\mathbf{2}^{\mathbf{2 , 6}}\right]$ decane, 12. Sodium, $(0.375 \mathrm{~g}, 2.2$ equiv.) was dissolved in dried absolute ethanol, $(30 \mathrm{~mL})$, over a $15 \mathrm{~min}$ period at room temperature. To this was added benzyl mercaptan $(1.93 \mathrm{~g}, 1.83 \mathrm{~mL}, 0.0152 \mathrm{~mol}$.) in a dropwise fashion. After stirring for 15 min a solution of bis-bromomethyl tricyclodecane $(2.45 \mathrm{~g}, 0.00760 \mathrm{~mol})$ in ethanol $(20 \mathrm{~mL})$ was added dropwise. The mixture was refluxed for $2 \mathrm{~h}$. Water, $(50 \mathrm{~mL})$ was then added and the mixture extracted with chloroform three times. The organic phase was dried $\left(\mathrm{MgSO}_{4}\right)$ and evaporated in vacuo to give the product as a yellow oil, (3.13 g, 100\%) which was used without any further purification. IR 
(film): 3060, 3026, 2944, 2871, 1493, 1452, 1285, 1231, 1070, 1028, $699 \mathrm{~cm}^{-1} ;{ }^{1} \mathrm{H} \mathrm{NMR}$ $\left(300 \mathrm{MHz}, \mathrm{CDCl}_{3}\right): 0.8-2.5(\mathrm{~m}, 18 \mathrm{H}), 3.6-3.8(\mathrm{~m}, 4 \mathrm{H}), 7.2-7.4(\mathrm{~m}, 10 \mathrm{H}) ;{ }^{13} \mathrm{C} \mathrm{NMR}(75$ $\mathrm{MHz}, \mathrm{CDCl}_{3}$ ): 30-55 (multiple peaks), 126.8, 128.4, 128.8, 138.7; LRMS (CI) m/z (rel. intensity): $409(\mathrm{M}+1), 367,321,285$. HRMS (CI): $\mathrm{m} / \mathrm{z}$ calcd. for $\mathrm{C}_{24} \mathrm{H}_{32} \mathrm{~S}_{2}\left(\mathrm{M}+\mathrm{H}^{+}\right)$ 409.2021, found 409.2023.

4,8-Bis(methylsulfonylchloride) tricyclo $\left[5.2 .1 .0^{2,6}\right]$ decane, 13. Benzylthioether, (7.15 g, $0.0175 \mathrm{~mol})$ was mixed with distilled water, $(10 \mathrm{~mL})$ and acetic acid, $(40 \mathrm{~mL})$ and stirred at $0^{\circ} \mathrm{C}$ for $5 \mathrm{~min}$. To this cooled solution was added chlorine gas (bubbled through at a rate of a couple of bubbles per second) over a $30 \mathrm{~min}$ period whilst maintaining the temperature below $10^{\circ} \mathrm{C}$. The solution was then left to stir for a further $5 \mathrm{~min}$ before the addition of water and chloroform. The mixture was extracted with chloroform and the combined organic phase was evaporated in vacuo. The yellow oil collected was subjected to a short path distillation at $100^{\circ} \mathrm{C}(\sim 5 \mathrm{~mm} / \mathrm{Hg})$ for fifteen minutes to remove benzyl chloride and benzyl acetate from the crude product. The crude oil was then purified by flash column chromatography which gave the product as a colorless oil, (3.25 g, 51\%). IR (film): 2956, 2879,1371, $1165 \mathrm{~cm}^{-1} ;{ }^{1} \mathrm{H}$ NMR (300 MHz, $\left.\mathrm{CDCl}_{3}\right): 1.2-2.7$ (m, 18H), 3.5-3.8 (m, 4H); ${ }^{13} \mathrm{C}$ NMR (75 MHz, $\left.\mathrm{CDCl}_{3}\right): 30-55$ (multiple peaks), 70.6, 70.8, 70.9, 71.1, 71.3, 71.4; LRMS (CI) m/z (rel. intensity): 393/394 (M+2CH4, 40), 361/362 (100), 329/330, 261/260, 197; HRMS (CI): m/z calcd for $\mathrm{C}_{12} \mathrm{H}_{18} \mathrm{~S}_{2} \mathrm{O}_{4} \mathrm{Cl}_{2}\left(\mathrm{M}+\mathrm{H}^{+}\right)$361.010183, found 361.010789; Anal. Calcd. for $\mathrm{C}_{12} \mathrm{H}_{18} \mathrm{~S}_{2} \mathrm{O}_{4} \mathrm{Cl}_{2}$ : C, 39.9; H, 4.99. Found C, 40.4; H, 4.99.

2-(tert-Butyldimethylsilanyloxy)-ethylamine, 14. Triethylamine, $(36.44 \mathrm{~g}, 52 \mathrm{~mL}, 0.36$ mol), was added to a solution of ethanolamine (10 g, $0.164 \mathrm{~mol})$ (freshly dried and 
distilled) and tert-butyldimethylsilylchloride (24.96 g, $0.164 \mathrm{~mol})$ in dichloromethane $(200 \mathrm{~mL})$. After stirring at room temperature for $16 \mathrm{~h}$ water $(30 \mathrm{~mL})$ was added and the two phases were separated. The organic phase was washed with brine, dried $\left(\mathrm{MgSO}_{4}\right)$ and evaporated in vacuo to yield a colorless oil, $(24.0 \mathrm{~g}, 87 \%)$ which was used without further purification. IR (film): 3545, 2967, 1355, $1175\left(\mathrm{~cm}^{-1}\right) ;{ }^{1} \mathrm{H}$ NMR (300 MHz, $\left.\mathrm{CDCl}_{3}\right): 1.64-1.83(\mathrm{~m}, 2 \mathrm{H}), 2.43(\mathrm{~s}, 3 \mathrm{H}), 3.84-3.95(\mathrm{~m}, 1 \mathrm{H}), 4.08-4.24(\mathrm{~m}, 2 \mathrm{H}), 7.34(\mathrm{~d}, J$ 8.5, 2H), $7.78(\mathrm{~d}, J 8.5,2 \mathrm{H}) ;{ }^{13} \mathrm{C} \mathrm{NMR}\left(75 \mathrm{MHz}, \mathrm{CDCl}_{3}\right)$ : 21.4, 23.3, 37.6, 63.7, 67.8, 127.6, 129.7, 132.7, 144.7; LRMS (CI) m/z (rel. intensity): 245 (100), 227 (50), 173 (20). HRMS (CI): $\mathrm{m} / \mathrm{z}$ calcd for $\mathrm{C}_{11} \mathrm{H}_{17} \mathrm{~S}_{1} \mathrm{O}_{4}\left(\mathrm{M}+\mathrm{H}^{+}\right)$245.0847, found 245.0837 . Methyl-3-[2-(tert-butyldimethylsilanyloxy)-ethylamino]-propionate, 15. A solution of methyl acrylate $(11.16 \mathrm{~g}, 0.103 \mathrm{~mol})$ in methanol $(20 \mathrm{~mL})$ was added, dropwise, over a period of $1 \mathrm{~h}$ to 2 -(tert-butyldimethylsilanyloxy)-ethylamine $(22.7 \mathrm{~g}, 0.103 \mathrm{~mol})$ in methanol, $(100 \mathrm{~mL})$ at $0{ }^{\circ} \mathrm{C}$. The mixture was allowed to warm to room temperature and was stirred for $18 \mathrm{~h}$. The solvent was evaporated in vacuo to yield the crude product. Purification by flash column chromatography eluting with 2:1 hexanes : ethyl acetate gave the product as a colorless oil (18.8 g, 56\%). IR (evap. film): 2953, 2928, 2856, 1743, $1472\left(\mathrm{~cm}^{-1}\right) ;{ }^{1} \mathrm{H}$ NMR (300 MHz, $\left.\mathrm{CDCl}_{3}\right):-0.24$ (s, 6H), 0.60 (s, 9H), 2.06 (bs, 1H), $2.21(\mathrm{t}, J 6.5,2 \mathrm{H}), 2.41(\mathrm{t}, J 5.4,2 \mathrm{H}), 2.60(\mathrm{t}, J 6.5,2 \mathrm{H}), 3.36(\mathrm{~s}, 3 \mathrm{H}), 3.41(\mathrm{t}, J 5.4$, $2 \mathrm{H}) ;{ }^{13} \mathrm{C}$ NMR (75 MHZ, $\left.\mathrm{CDCl}_{3}\right)$ : -6.3, 18.0, 25.6, 34.3, 45.1 0.9, 50.9, 62.3, 172.3; LRMS (CI) m/z (rel. intensity): 262 (100), 246 (30). HRMS (CI): m/z calcd for $\mathrm{C}_{12} \mathrm{H}_{28} \mathrm{O}_{3} \mathrm{SiN}\left(\mathrm{M}+\mathrm{H}^{+}\right)$262.1838, found 262.184; Anal. Calcd. for $\mathrm{C}_{12} \mathrm{H}_{27} \mathrm{NO}_{3} \mathrm{Si}$ : C, 55.2; H, 10.35; N, 5.36. Found C, 56.1; H, 10.54, N, 5.24. 


\section{Methyl- $N$-3-[2-(tert-butyldimethylsilanyloxy)-ethyl]- $N$-(2-methoxycarbonylethyl)-}

malonamate, 16. Methyl-3-[2-(tert-butyldimethylsilanyloxy)-ethylamino]-propionate (9.2 $\mathrm{g}, 0.0352 \mathrm{~mol})$ was mixed with dimethylmalonate $(35 \mathrm{~mL})$. The mixture was heated to $180-190{ }^{\circ} \mathrm{C}$ over a period of $2 \mathrm{~h}$. The colorless mixture turned pale yellow. The mixture was cooled and the dimethyl malonate was evaporated in vacuo. The product, (11.7 g, $92 \%$ ) was used without further purification. IR (evap. film): 2952, 2928, 2856, 1741, $1652\left(\mathrm{~cm}^{-1}\right) ;{ }^{1} \mathrm{H}$ NMR (300 MHz, $\left.\mathrm{CDCl}_{3}\right):-0.42$ (s, 6H), 0.79 (s, 9H), 2.57 (t, $J$ $7.0,2 \mathrm{H}), 3.37(\mathrm{t}, J 5.0,2 \mathrm{H}), 3.46-3.651(\mathrm{~m}, 12 \mathrm{H}) ;{ }^{13} \mathrm{C} \mathrm{NMR}\left(75 \mathrm{MHz}, \mathrm{CDCl}_{3}\right)$ (keto / enol forms): $-6.4,18.0,25.6,32.1,33.1,40.7,41.1,42.4,45.4,48.5,51.1,51.5,51.7$, 52.2, 60.2, 60.8, 61.2, 165.2, 166.6, 168.1, 172.3; LRMS (CI) m/z (rel. intensity): 362 (100), 304 (45). HRMS (CI): m/z calcd for $\mathrm{C}_{16} \mathrm{H}_{32} \mathrm{O}_{6} \mathrm{NSi}\left(\mathrm{M}+\mathrm{H}^{+}\right) 362.19989$, found 362.20009; Anal. Calcd. for $\mathrm{C}_{16} \mathrm{H}_{31} \mathrm{NO}_{6}: \mathrm{C}, 53.19 ; \mathrm{H}, 8.59 ; \mathrm{N}, 3.87$. Found $\mathrm{C}, 53.10 ; \mathrm{H}$, $8.69 ; \mathrm{N}, 3.87$.

\section{1-[2-(tert Butyldimethylsilanyloxy)-ethyl]-2,4-dioxo-piperidine-3-carboxylic acid}

methyl ester, 17. A solution of methyl- $N-3$-[2-(tert-butyldimethylsilanyloxy)-ethyl]- $N$ (2-methoxycarbonyl-ethyl)-malonamate, $(10.80 \mathrm{~g}, 0.0300 \mathrm{~mol})$ in dried toluene $(15 \mathrm{~mL})$ was added, over a period of $1 \mathrm{~h}$, to a mixture of potassium carbonate $(20.4 \mathrm{~g}, 0.148 \mathrm{~mol})$ and 18-crown-6 ether, $(0.77 \mathrm{~g}, 0.0029 \mathrm{~mol})$ in dried toluene $(100 \mathrm{~mL})$ at reflux. The mixture was heated at reflux for 6 hours, cooled and poured into a separating funnel. The flask was washed with water, $(4 \times 100 \mathrm{~mL})$ and transferred into the funnel. The funnel contents were swirled rather than shaken to avoid the formation of an emulsion. The aqueous phase was separated and the organic phase washed with water $(2 \times 100 \mathrm{~mL})$. The aqueous phase was chilled in an ice bath and stirred with dichloromethane $(200 \mathrm{~mL})$. The 
basic solution was acidified ( $\mathrm{pH} 1)$ with $6 \mathrm{~N} \mathrm{HCl}$ solution and separated immediately. The aqueous phase was saturated with brine and extracted with dichloromethane, $(2 \mathrm{x}$ $200 \mathrm{~mL}$ ). The combined organic phases were evaporated in vacuo. The product was obtained as an orange oil, $(6.1 \mathrm{~g}, 62 \%)$ and used without further purification. IR (film): 2953, 2931, 2858, 1740, $1653\left(\mathrm{~cm}^{-1}\right) ;{ }^{1} \mathrm{H}$ NMR (300 MHz, $\left.\mathrm{CDCl}_{3}\right):-0.04$ (s, 6H), 0.80 (s, $9 \mathrm{H}), 2.54(\mathrm{t}, J 6.7,2 \mathrm{H}), 3.36-3.46(\mathrm{~m}, 4 \mathrm{H}), 3.68(\mathrm{t}, J 5.3,2 \mathrm{H}), 3.81(\mathrm{~s}, 3 \mathrm{H}) ;{ }^{13} \mathrm{C} \mathrm{NMR}$ (75MHz, $\left.\mathrm{CDCl}_{3}\right):-5.4,18.0,25.6,25.8,29.7,44.6,49.7,52.3,62.2,162.1,172.2,183.2$; LRMS (CI) m/z (rel. intensity): 272 (100), 300 (15), 330 (15). HRMS (CI): m/z calcd for $\mathrm{C}_{15} \mathrm{H}_{28} \mathrm{O}_{5} \mathrm{NSi}\left(\mathrm{M}+\mathrm{H}^{+}\right)$330.1733, found 330.1737 .

1-[2-(tert-Butyldimethylsilanyloxy)-ethyl]-piperidine-2,4-dione, 18. A solution of 1[2-(tert-butyldimethyl-silanyloxy)-ethyl]-2,4-dioxo-piperidine-3-carboxylic acid methyl ester $(6.13 \mathrm{~g}, 0.0186 \mathrm{~mol})$ in acetonitrile $(80 \mathrm{~mL})$ and water $(1 \mathrm{~mL})$ was heated at reflux for $2.5 \mathrm{~h}$ then cooled and evaporated in vacuo. The material was collected as a crude orange oil, 3.5g. Purification by flash column chromatography using 2:1 hexanes:ethyl acetate gave a colorless oil, (2.90 g, 58 \%). IR (film): 2953, 2929, 2884, 2857, 1730, $1663\left(\mathrm{~cm}^{-1}\right) ;{ }^{1} \mathrm{H} \mathrm{NMR}\left(300 \mathrm{MHz}, \mathrm{CDCl}_{3}\right):-0.03(\mathrm{~s}, 6 \mathrm{H}), 0.80(\mathrm{~s}, 9 \mathrm{H}), 2.53(\mathrm{t}, J 6.2,2 \mathrm{H})$, $3.25(\mathrm{~s}, 2 \mathrm{H}), 3.52(\mathrm{t}, J 5.2,2 \mathrm{H}), 3.66(\mathrm{t}, J 6.2,2 \mathrm{H}), 3.71(\mathrm{t}, J 5.2,2 \mathrm{H}) ;{ }^{3} \mathrm{C} \mathrm{NMR}(\mathrm{MHz}$, $\mathrm{CDCl}_{3}$ ): -5.6, 17.9, 25.7, 38.6, 45.3, 48.9, 61.8, 166.1, 203.7; LRMS (CI) m/z (rel. intensity): 272 (100), 140 (25). HRMS (CI): $\mathrm{m} / \mathrm{z}$ calcd for $\mathrm{C}_{13} \mathrm{H}_{26} \mathrm{O}_{3} \mathrm{NSi}\left(\mathrm{M}+\mathrm{H}^{+}\right)$ 272.16820, found 272.16831; Anal. Calcd. for $\mathrm{C}_{15} \mathrm{H}_{27} \mathrm{NO}_{5} \mathrm{Si}$ : C, 54.7; H, 8.21. Found C, $55.0 ; \mathrm{H}, 8.69$.

1-[2-(tert-Butyldimethylsilanyloxy)-ethyl]-3-diazo-piperidine-2,4-dione, 19. To a solution of 1-[2-(tert-butyldimethylsilanyloxy)-ethyl]-piperidine-2,4-dione (3.68 g, 
$0.0136 \mathrm{~mol})$ in dried acetonitrile $(50 \mathrm{~mL})$ at $0^{\circ} \mathrm{C}$ was added toluene sulfonylazide, $(2.68$ g, $0.0136 \mathrm{~mol})$ followed by $N$-methyl morpholine, $(1.40 \mathrm{~g}, 0.0139 \mathrm{~mol})$. The mixture was allowed to warm to room temperature over a period of $2 \mathrm{~h}$. The solvents were evaporated in vacuo. Purification by flash column chromatography eluting with chloroform gave the product as a pale green oil (3.69 $\mathrm{g}, 92 \%)$. IR (film):2934, 2138, 1667, 1663, $1487\left(\mathrm{~cm}^{-1}\right)$;

$\left.{ }_{1}^{1} \mathrm{H} \mathrm{NMR} \mathrm{(300} \mathrm{MHz,} \mathrm{CDCl}_{3}\right):-0.02(\mathrm{~s}, 6 \mathrm{H}), 0.81$ (s, 9H), 2.56 (t, $J$ 6.3, 2H), 3.52 (t, J 5.0, 2H), $3.56(\mathrm{t}, J 6.3,2 \mathrm{H}), 3.72(\mathrm{t}, J 5.0,2 \mathrm{H}) ;{ }^{13} \mathrm{C} \mathrm{NMR}\left(75 \mathrm{MHZ}, \mathrm{CDCl}_{3}\right):-5.6,18.0,25.7$, 36.6, 44.8, 49.8, 61.9, 76.1, 160.1, 188.1; LRMS (CI) m/z (rel. intensity): 298 (100), 240 (15); HRMS (CI): $\mathrm{m} / \mathrm{z}$ calcd for $\mathrm{C}_{13} \mathrm{H}_{24} \mathrm{O}_{3} \mathrm{~N}_{3} \mathrm{Si}\left(\mathrm{M}+\mathrm{H}^{+}\right)$298.1587, found 298.1580 .

3-Diazo-1-(2-hydroxyethyl)-piperidine-2,4-dione, 20. Aqueous HF (48 \%), (1.07 g, $0.026 \mathrm{~mol}$ ) was added to a solution of 1-[2-(tert-butyldimethylsilanyloxy)-ethyl]-3-diazopiperidine-2,4-dione, $(3.85 \mathrm{~g}, 0.0130 \mathrm{~mol})$ in acetonitrile $(25 \mathrm{~mL})$ at $0^{\circ} \mathrm{C}$. After $1 \mathrm{~h}$ at room temperature the mixture was warmed to $40{ }^{\circ} \mathrm{C}$ for $0.5 \mathrm{~h}$ before being quenched by the addition of solid sodium bicarbonate until neutral $\mathrm{pH}$. The solid was removed by filtration and the filtrate evaporated in vacuo. The product was obtained as a colorless oil, (2.25 g, $95 \%$ ) and used without any further purification. IR (film): 3412, 2935, 2878, 2136, 1643, $1635\left(\mathrm{~cm}^{-1}\right) ;{ }^{1} \mathrm{H}$ NMR (300 MHz, $\left.\mathrm{CDCl}_{3}\right): 1.87(\mathrm{~s}, 1 \mathrm{H}), 2.57(\mathrm{t}, J 6.5,2 \mathrm{H})$, 3.49 - $3.53(\mathrm{~m}, 4 \mathrm{H}), 3.66(\mathrm{t}, J 5.3,2 \mathrm{H}) ;{ }^{13} \mathrm{C} \mathrm{NMR}\left(75 \mathrm{MHz}, \mathrm{CDCl}_{3}\right)$ : 36.2, 44.0, 49.7, 60.4, 75.6, 161.0, 188.1; LRMS (CI) m/z (rel. intensity): 298 (100), 240 (15); HRMS (CI): $\mathrm{m} / \mathrm{z}$ calcd for $\mathrm{C}_{7} \mathrm{H}_{10} \mathrm{O}_{3} \mathrm{~N}_{3}\left(\mathrm{M}+\mathrm{H}^{+}\right)$184.07222, found 184.07213; Anal. Calcd. for $\mathrm{C}_{7} \mathrm{H}_{9} \mathrm{~N}_{3} \mathrm{O}_{3}: \mathrm{C}, 45.90 ; \mathrm{H}, 4.92 ; \mathrm{N}, 22.82$. Found C, 46.00; H, 5.25; N, 20.55. 


\section{4,8-Bis-(3-diazo-1-(2-oxyethyl-(methylsulfonyl))-piperidine-2,4-dione)}

tricyclo[5.2.1.0 ${ }^{2,6}$ ]decane, 21. $N$-Methylmorpholine (1.64 g, $\left.0.0191 \mathrm{~mol}\right)$ was added to a solution of 3-diazo-1-(2-hydroxyethyl)-piperidine-2,4-dione (1.48 g, $0.00809 \mathrm{~mol})$ in dried dichloromethane, $(30 \mathrm{~mL})$ at $0^{\circ} \mathrm{C}$. After stirring for $10 \mathrm{~min}$ a homogeneous solution formed. To this was added a solution of 4,8-bis(methylsulfonylchloride) tricyclo[5.2.1.0 $\left.0^{2,6}\right]$ decane $(1.45 \mathrm{~g}, 0.00402 \mathrm{~mol})$ in dichloromethane $(5 \mathrm{~mL})$ and the resultant solution was allowed to warm to room temperature and stirred overnight. The organic phase was washed with hydrochloric acid (1M, $20 \mathrm{~mL})$ and brine $(20 \mathrm{~mL})$, dried $\left(\mathrm{MgSO}_{4}\right)$. Removal of the solvent in vacuo gave a clear, light green oil, (2.78 g, 100\%) which was used without further purification. IR (film): 2953, 2136, 1643, 1348, 1165 $\mathrm{cm}^{-1} ;{ }^{1} \mathrm{H}$ NMR $\left(300 \mathrm{MHz}, \mathrm{CDCl}_{3}\right):$ 0.89-2.58 (m, 14H), $2.67(\mathrm{t}, J$ 6.4, 4H), 3.04-3.08 (m, 4H), 3.57-3.62 (m, 4H), 3.71-3.80 (m, 4H), 4.38-4.39 (m, 4H); ${ }^{3} \mathrm{C}$ NMR (75 MHz, $\mathrm{CDCl}_{3}$ ): 30-60 (multiple peaks), 67.5, 75.7, 160.9, 187.7; FAB LRMS m/z (rel. intensity): 655 (50), 307 (100), 289 (60); FAB HRMS: m/z calcd for $\mathrm{C}_{26} \mathrm{H}_{35} \mathrm{O}_{10} \mathrm{~N}_{6} \mathrm{~S}_{2}$ $\left(\mathrm{M}+\mathrm{H}^{+}\right)$655.18561, found 655.18593; Anal. Calcd. for $\mathrm{C}_{26} \mathrm{H}_{34} \mathrm{~N}_{6} \mathrm{~S}_{2} \mathrm{O}_{10}$ : C, 47.7; H, 5.20; N, 12.8. Found C, 46.0; H, 5.21; N, 11.9.

Synthetic Procedure for Dissolution Inhibitor, 30

4-Benzyloxybenzonitrile, 22. Benzyl chloride (20 g, $0.161 \mathrm{~mol})$ was added to a suspension of 4-hydroxy-benzonitrile $(16.0 \mathrm{~g}, 0.1345 \mathrm{~mol})$, potassium carbonate $(22 \mathrm{~g}$, $0.159 \mathrm{~mol})$ and potassium iodide $(3.0 \mathrm{~g}, 0.0181 \mathrm{~mol})$ in dried DMF $(120 \mathrm{~mL})$. The mixture was left to stir at room temperature overnight. Water $(300 \mathrm{~mL})$ was added and the mixture extracted with diethyl ether $(3 \times 100 \mathrm{~mL})$. The combined organic phase was 
washed with brine, dried $\left(\mathrm{MgSO}_{4}\right)$ and the solvents evaporated in vacuo. Excess benzyl chloride was removed on the high vacuum rotary evaporator. The crude product was recrystallized from diethyl ether to give the product as a white powder, $(27.5 \mathrm{~g}, 98 \%)$. Mp 83-86 ${ }^{\circ}$ C. IR (film): 2221, 1603, $1508 \mathrm{~cm}^{-1}$; ${ }^{1} \mathrm{H}$ NMR (300 MHz, $\mathrm{CDCl}_{3}$ ): 4.53 (s, 2H), $6.95(\mathrm{~d}, J 8.6,2 \mathrm{H}), 7.29-7.39(\mathrm{~m}, 5 \mathrm{H}), 7.50(\mathrm{~d}, J 8.6,2 \mathrm{H}) ;{ }^{13} \mathrm{C} \mathrm{NMR}(75 \mathrm{MHz}$, $\left.\mathrm{CDCl}_{3}\right): 70.0,103.9,115.4,118.9,127.2,128.1,128.5,133.7,161.7 ;$ LRMS (CI) m/z (rel. intensity): 210 (100), 120 (10); HRMS (CI): m/z calcd for $\mathrm{C}_{14} \mathrm{H}_{12} \mathrm{ON}\left(\mathrm{M}+\mathrm{H}^{+}\right)$ 210.0919, found 210.0910: Anal. Calcd. for $\mathrm{C}_{14} \mathrm{H}_{11} \mathrm{NO}$ : C, 80.36; H, 5.30; N, 6.69. Found C, 80.47; H, 5.19; N, 6.78.

4-Benzyloxybenzylamine, 23. To a solution of 4-benzyloxybenzonitrile (9.8 g, 0.0467 mol) in dried diethyl ether $(180 \mathrm{~mL})$ at $0^{\circ} \mathrm{C}$ was added, portionwise, $\mathrm{LiAlH}_{4},(2.25 \mathrm{~g}$, mol) and $\mathrm{AlCl}_{3}(2.7 \mathrm{~g}, \mathrm{~mol})$. The mixture was allowed to warm to room temperature and stirred overnight. The reaction was quenched by the addition of ice (total of $20 \mathrm{~mL}$ ) over a period of $1 \mathrm{~h}$. A solid formed which was washed with diethyl ether $(3 \times 100 \mathrm{~mL})$ and ethyl acetate $(100 \mathrm{~mL})$. The combined organic phase was dried $\left(\mathrm{MgSO}_{4}\right)$ and evaporated in vacuo to yield a yellow oil which solidified to a low melting material, $(8.90 \mathrm{~g}, 89 \%)$.

IR (film): 3400, 3064, 3032, 2915, 2865, 1608, $1510 \mathrm{~cm}^{-1} ;{ }^{1} \mathrm{H}$ NMR (300 MHz, $\mathrm{CDCl}_{3}$ ): $1.55(\mathrm{~s}, 2 \mathrm{H}), 3.78(\mathrm{~s}, 2 \mathrm{H}), 5.03(\mathrm{~s}, 2 \mathrm{H}), 6.93(\mathrm{~d}, J 8.6,2 \mathrm{H}), 7.21(\mathrm{~d}, J 8.6,2 \mathrm{H}), 7.30-7.43$ (m, 5H); ${ }^{13} \mathrm{C} \mathrm{NMR}\left(75 \mathrm{MHz}, \mathrm{CDCl}_{3}\right): 45.8,70.0,114.9,127.3,127.8,128.2,128.5$, 135.8, 137.0, 157.6; LRMS (CI) m/z (rel. intensity): 655 (50), 307 (100), 289 (60); HRMS (CI): $\mathrm{m} / \mathrm{z}$ calcd for $\mathrm{C}_{14} \mathrm{H}_{15} \mathrm{ON}\left(\mathrm{M}^{+}\right)$213.1154, found 213.1146; Anal. Calcd. for $\mathrm{C}_{14} \mathrm{H}_{15} \mathrm{NO}$ : C, 78.8; H, 7.04; N, 6.57. Found C, 78.2; H, 7.09; N, 6.36. 
3-(4-Benzyloxybenzylamino)-propionic acid methyl ester, 24. A solution of methyl acrylate $(10.7 \mathrm{~g}, 0.0950 \mathrm{~mol})$ in methanol $(50 \mathrm{~mL})$ was added dropwise over a period of 1 $\mathrm{h}$ to a solution of 4-benzyloxybenzylamine $(23.9 \mathrm{~g}, 0.112 \mathrm{~mol})$ in methanol $(350 \mathrm{~mL})$ at $0^{\circ} \mathrm{C}$. The mixture was allowed to warm to room temperature and was stirred for a further $18 \mathrm{~h}$. Evaporation of the solvent in vacuo yielded the crude product, $31.3 \mathrm{~g}$. Purification by flash column chromatography eluting with hexanes: ethyl acetate, $2: 1$ gave the desired compound as a colorless oil, (22.5g, 67\%). IR (film): 3320, 3031, 2950, 2841, 1734, $1511 \mathrm{~cm}^{-1} ;{ }^{1} \mathrm{H}$ NMR $\left(300 \mathrm{MHz}, \mathrm{CDCl}_{3}\right): 1.72(\mathrm{~s}, 2 \mathrm{H}), 2.50(\mathrm{t}, J 6.5,2 \mathrm{H}), 2.86(\mathrm{t}, J 6.5$, 2H), $3.64(\mathrm{~s}, 2 \mathrm{H}), 3.71(\mathrm{~s}, 2 \mathrm{H}), 5.02(\mathrm{~s}, 2 \mathrm{H}), 6.91(\mathrm{~d}, J 8.6,2 \mathrm{H}), 7.21(\mathrm{~d}, J 8.6,2 \mathrm{H}), 7.28-$ 7.42 (m, 5H); ${ }^{13} \mathrm{C}$ NMR (75 MHz, $\left.\mathrm{CDCl}_{3}\right): 34.5,44.3,51.4,53.0,69.9,114.7,127.3$, 127.7, 128.4, 129.1, 132.5, 137.0, 157.7, 173.0; LRMS (CI) m/z (rel. intensity): 300 (30), 197 (100); HRMS (CI): m/z calcd for $\mathrm{C}_{18} \mathrm{H}_{22} \mathrm{O}_{3} \mathrm{~N}\left(\mathrm{M}+\mathrm{H}^{+}\right) 300.1600$, found 300.1591; Anal. Calcd. for $\mathrm{C}_{18} \mathrm{H}_{21} \mathrm{NO}_{3}$ : C, 72.22; H, 7.07; N, 4.68. Found C, 71.93; H, $7.04 ; \mathrm{N}, 4.66$.

$N$-(4-Benzyloxybenzyl)- $N$-(2-methoxycarbonyl-ethyl)-malonamic acid methyl ester, 25. 3-(4-Benzyloxybenzylamino)-propionic acid methyl ester (12.0 g, $0.0401 \mathrm{~mol})$ was mixed with dimethylmalonate, $(50 \mathrm{~mL})$. The mixture was heated to $180-190{ }^{\circ} \mathrm{C}$ over a period of $2 \mathrm{~h}$. The colorless mixture turned pale yellow. The mixture was cooled and the dimethylmalonate was evaporated in vacuo on a high vacuum rotary evaporator. The crude product, $(13.6 \mathrm{~g}, 85 \%$ ) was used without further purification. IR (film): 3320, 2952, 1734, 1652, $\left.1511 \mathrm{~cm}^{-1} ;{ }^{1} \mathrm{H} \mathrm{NMR} \mathrm{(300} \mathrm{MHz,} \mathrm{CDCl}_{3}\right)$ (mixture of rotomers): $2.53(\mathrm{t}, J$ 6.9, 2H), $2.62(\mathrm{t}, J 6.9,2 \mathrm{H}), 3.79-3.46(\mathrm{~m}, 20 \mathrm{H}), 4.50(\mathrm{~s}, 2 \mathrm{H}), 4.55(\mathrm{~s}, 2 \mathrm{H}), 5.02(\mathrm{~s}, 2 \mathrm{H})$, $5.04(\mathrm{~s}, 2 \mathrm{H}), 6.91(\mathrm{~d}, J 8.7,2 \mathrm{H}), 6.96(\mathrm{~d}, J 8.7,2 \mathrm{H}), 7.10(\mathrm{~d}, J 8.6,2 \mathrm{H}), 7.18(\mathrm{~d}, J 8.6$, 
2H), 7.31-7.43 (m, 10H); ${ }^{13} \mathrm{C} \mathrm{NMR}\left(75 \mathrm{MHz}, \mathrm{CDCl}_{3}\right)$ (mixture of rotomers): 32.0, 32.7, $40.7,41.0,42.6,42.7,42.7,47.2,51.4,51.7,52.0,52.2,69.9,114.9,115.2,127.2,127.6$, $127.7,127.8,128.1,128.4,128.9,129.1,136.6,136.8,158.1,158.3,166.1,166.3,167.7$, 167.9, 171.1, 172.1; LRMS (CI) m/z (rel. intensity): 400 (30), 197 (100); HRMS (CI): $\mathrm{m} / \mathrm{z}$ calcd for $\mathrm{C}_{22} \mathrm{H}_{26} \mathrm{O}_{6} \mathrm{~N}\left(\mathrm{M}+\mathrm{H}^{+}\right)$400.1760, found 400.1756; Anal. Calcd. for $\mathrm{C}_{22} \mathrm{H}_{25} \mathrm{NO}_{6}: \mathrm{C}, 66.1 ; \mathrm{H}, 6.26 ; \mathrm{N}, 3.50$. Found C, 64.4; H, 6.19; N, 3.43.

$N$-(4-Benzyloxybenzyl)-2,4-dioxo-piperidine-3-carboxylic acid methyl ester, 26. A solution of $N$-(4-benzyloxybenzyl)- $N$-(2-methoxycarbonyl-ethyl)-malonamic acid methyl ester $(6.6 \mathrm{~g}, 0.0165 \mathrm{~mol})$ in dried toluene $(20 \mathrm{~mL})$. was added, over a period of $1 \mathrm{~h}$, to a mixture of potassium carbonate $(11.25 \mathrm{~g}, 0.082 \mathrm{~mol})$ and 18-crown- 6 ether $(0.40 \mathrm{~g}$, $0.0015 \mathrm{~mol})$ in toluene $(80 \mathrm{~mL})$ at reflux. The mixture was heated at reflux for 6 hours before being worked up. The material was cooled and poured into a separating funnel. The flask was washed with water $(4 \times 60 \mathrm{~mL})$ and this was transferred into the funnel. The funnel was swirled rather than shaken to avoid the formation of an emulsion. The aqueous phase was separated and the organic phase washed with water $(2 \times 60 \mathrm{~mL})$. The aqueous phase was chilled in an ice bath and stirred with dichloromethane $(100 \mathrm{~mL})$. The basic solution was acidified to $\mathrm{pH} 1$ with $6 \mathrm{~N} \mathrm{HCl}$ solution and separated immediately. The aqueous phase was saturated with brine and extracted with dichloromethane $(2 \times 100$ $\mathrm{mL})$. The combined organic phase was dried $\left(\mathrm{MgSO}_{4}\right)$ and evaporated in vacuo. The product was obtained as an orange oil, $(4.56 \mathrm{~g}, 75 \%)$ which was used without any further purification. IR (film): 3032, 2951, 1733, $1653 \mathrm{~cm}^{-1} ;{ }^{1} \mathrm{H}$ NMR (300 MHz, $\mathrm{CDCl}_{3}$ ): 2.53 (t, $J 6.8,2 \mathrm{H}), 3.26(\mathrm{t}, J 6.8,2 \mathrm{H}), 3.63(\mathrm{~s}, 1 \mathrm{H}), 3.89(\mathrm{~s}, 3 \mathrm{H}), 4.54(\mathrm{~s}, 2 \mathrm{H}), 5.00(\mathrm{~s}, 2 \mathrm{H})$, $6.91(\mathrm{~d}, J 8.5,2 \mathrm{H}), 7.13-7.42(\mathrm{~m}, 7 \mathrm{H}) ;{ }^{13} \mathrm{C} \mathrm{NMR}\left(75 \mathrm{MHz}, \mathrm{CDCl}_{3}\right): 23.9,41.3,48.8$, 
$52.3,69.9,70.3,114.8,127.2,128.0,128.4,129.2,129.8,136.8,158.1,162.0,172.1$, 182.8; LRMS (CI) m/z (rel. intensity): 300 (30), 197 (100); HRMS (CI): m/z calcd for $\mathrm{C}_{21} \mathrm{H}_{22} \mathrm{O}_{5} \mathrm{~N}\left(\mathrm{M}+\mathrm{H}^{+}\right)$368.14980, found 368.14934; Anal. Calcd. for $\mathrm{C}_{21} \mathrm{H}_{21} \mathrm{NO}_{5}: \mathrm{C}$, 68.6; H, 5.72; N, 3.82. Found C, 68.1; H, 6.00; N, 3.95.

$N$-(4-Benzyloxybenzyl)-piperidine-2,4-dione, 27. $N$-(4-Benzyloxybenzyl)-2,4-dioxopiperidine-3-carboxylic acid methyl ester (23.1 g, $0.0629 \mathrm{~mol})$ was dissolved in acetonitrile $(150 \mathrm{~mL})$ and water $(5 \mathrm{~mL})$. The mixture was heated at reflux for $2.5 \mathrm{~h}$ before being cooled and the solvents evaporated in vacuo. The material was collected as a crude yellow solid, $18.5 \mathrm{~g}$. This was purified by recrystallization from methanol to yield white, plate like crystals, (12.50g, 64\%). Mp 119-120 ${ }^{\circ} \mathrm{C}$. IR (film): 3063, 3027, 2919, 2884, $2858,1718,1653 \mathrm{~cm}^{-1} ;{ }^{1} \mathrm{H} \mathrm{NMR}\left(300 \mathrm{MHz}, \mathrm{CDCl}_{3}\right): 2.51(\mathrm{t}, J 8.3,2 \mathrm{H}), 3.40(\mathrm{~s}, 2 \mathrm{H})$, $3.46(\mathrm{t}, J 8.3,2 \mathrm{H}), 4.62(\mathrm{~s}, 2 \mathrm{H}), 5.05(\mathrm{~s}, 2 \mathrm{H}), 6.94(\mathrm{~d}, J 8.7,2 \mathrm{H}), 7.20(\mathrm{~d}, J 8.7,2 \mathrm{H}), 7.35-$ $7.42(\mathrm{~m}, 5 \mathrm{H}) ;{ }^{13} \mathrm{C} \mathrm{NMR}\left(75 \mathrm{MHz}, \mathrm{CDCl}_{3}\right): 38.6,42.1,48.9,49.4,70.0,115.2,127.4$, 128.0, 128.5, 128.5, 129.5, 136.8, 158.5, 166.2, 205.0; LRMS (CI) m/z (rel. intensity): 310 (75), 197 (100); HRMS (CI): m/z calcd for $\mathrm{C}_{19} \mathrm{H}_{20} \mathrm{O}_{3} \mathrm{~N}\left(\mathrm{M}+\mathrm{H}^{+}\right)$310.1443, found 310.1435; Anal. Calcd. for $\mathrm{C}_{19} \mathrm{H}_{19} \mathrm{NO}_{3}: \mathrm{C}, 73.78 ; \mathrm{H}, 6.15 ; \mathrm{N}, 4.53$. Found C, 73.50; H, $6.17 ; \mathrm{N}, 4.51$.

$N$-(4-Hydroxybenzyl)-piperidine-2,4-dione, 28. 10\% Palladium on charcoal ( $0.4 \mathrm{~g}, 8 \%$ (w/w)) was added to a solution of $N$-(4-benzyloxybenzyl)-piperidine-2,4-dione $(5.0 \mathrm{~g}$, $0.0161 \mathrm{~mol})$ in methanol $(80 \mathrm{~mL})$ in a parr bomb glass insert. The vessel was flushed with hydrogen 3 times and placed under 30 p.s.i. pressure. The mixture was stirred overnight. The hydrogen used was replaced and the mixture left to stir for a further $4 \mathrm{~h}$. The mixture was filtered twice using a filter aid and the solvent evaporated in vacuo to 
yield a clear glassy solid, (3.3 g, 93\%). IR (film): 3146, 1728,1635, 1616, 1594, 1516 $\mathrm{cm}^{-1} ;{ }^{1} \mathrm{H}$ NMR (300 MHz, $\left.\mathrm{CD}_{3} \mathrm{OD}\right): 2.43(\mathrm{t}, J 6.2,2 \mathrm{H}), 3.46(\mathrm{t}, J 6.2,2 \mathrm{H}), 4.52(\mathrm{~s}, 2 \mathrm{H})$, 6.73 (d, $J 8.5,2 \mathrm{H}), 7.09$ (d, $J 8.5,2 \mathrm{H}) ;{ }^{13} \mathrm{C}$ NMR $\left(75 \mathrm{MHz}, \mathrm{CD}_{3} \mathrm{OD}\right): 39.0,43.4,48.7$, 50.3, 116.5, 128.5, 130.5, 158.1, 169.0, 205.8; LRMS (CI) m/z (rel. intensity): 220 (100), 206 (30), 107 (55); HRMS (CI): $\mathrm{m} / \mathrm{z}$ calcd for $\mathrm{C}_{12} \mathrm{H}_{14} \mathrm{O}_{3} \mathrm{~N}\left(\mathrm{M}+\mathrm{H}^{+}\right)$220.09737, found 220.09723; Anal. Calcd. for $\mathrm{C}_{12} \mathrm{H}_{13} \mathrm{NO}_{3}: \mathrm{C}, 65.75 ; \mathrm{H}, 5.94 ; \mathrm{N}, 6.39$. Found $\mathrm{C}$, 65.64; H, 6.11; N, 6.24.

3-Diazo- $N$-(4-hydroxybenzyl)-piperidine-2,4-dione, 29. To a solution of $N$-(4hydroxy-benzyl)-piperidine-2,4-dione $(1.77 \mathrm{~g}, 0.00808 \mathrm{~mol})$ in methanol $(30 \mathrm{~mL})$ at $0^{\circ} \mathrm{C}$ was added toluene sulfonylazide $(1.61 \mathrm{~g}, 0.00815 \mathrm{~mol})$ followed by $N$-methyl morpholine $(1.53 \mathrm{~g}, 0.0177 \mathrm{~mol})$. The mixture was allowed to warm to room temperature over a period of $2 \mathrm{~h}$. The solvents were evaporated in vacuo and the residual solvent removed on the high vacuum. The crude material, a viscous oil, was purified by flash column chromatography using $1 \%$ methanol in chloroform. The product was obtained as a colorless oil, (1.11 g, 56\%). IR (film): 3357, 3261, 2137, 1652, 1635, $1616 \mathrm{~cm}^{-1} ;{ }^{1} \mathrm{H}$ NMR (300 MHz, $\left.\mathrm{CDCl}_{3}\right): 2.58$ (t, $\left.J 7.6,2 \mathrm{H}\right), 3.36(\mathrm{t}, J 7.6,2 \mathrm{H}), 4.57$ (s, 2H), 6.79 (d, $J$ 8.4, 2H), $7.12(\mathrm{~d}, J 8.4,2 \mathrm{H}) ;{ }^{13} \mathrm{C} \mathrm{NMR}\left(75 \mathrm{MHz}, \mathrm{CDCl}_{3}\right): 36.2,41.8,49.7,76.1,115.8$, 127.2, 129.5, 156.2, 160.6, 188.1; LRMS (CI) m/z (rel. intensity): 246 (40), 172 (100); HRMS (CI): $\mathrm{m} / \mathrm{z}$ calcd for $\mathrm{C}_{12} \mathrm{H}_{12} \mathrm{O}_{3} \mathrm{~N}_{3}\left(\mathrm{M}+\mathrm{H}^{+}\right)$246.08787, found 246.08723; Anal. Calcd. for $\mathrm{C}_{12} \mathrm{H}_{11} \mathrm{~N}_{3} \mathrm{O}_{3}$ : C, 58.77; H, 4.52 N, 17.13. Found C, 59.25; H, 4.66, N 15.42.

\section{4,8-Bis-(3-diazo- $N$-(4-benzyloxymethylsulfonyl)-piperidine-2,4-dione)-}

tricyclo[5.2.1.0 $\left.{ }^{2,6}\right]$ decane, 30. $N$-Methyl morpholine $(1.09 \mathrm{~g}, 0.0127 \mathrm{~mol})$ was added to a solution of 3-diazo- $N$-(4-hydroxybenzyl)-piperidine-2,4-dione (1.11 g, $0.00453 \mathrm{~mol})$ in 
dried dichloromethane $(25 \mathrm{~mL})$ at $0^{\circ} \mathrm{C}$. After $10 \mathrm{~min}$ a homogeneous solution had formed. To this was added a solution of bis(methylsulfonylchloride)-tricyclodecane $(0.915 \mathrm{~g}, 0.00253 \mathrm{~mol})$ in dichloromethane $(5 \mathrm{~mL})$. The solution was allowed to warm to room temperature and stirred overnight. The organic phase was evaporated in vacuo then dissolved in acetone $(5-6 \mathrm{~mL})$ and precipitated into an ice cold $1 \mathrm{M} \mathrm{HCl}$ solution $(50 \mathrm{~mL})$. The solution was filtered and the solid collected was dissolved in chloroform, dried $\left(\mathrm{MgSO}_{4}\right)$ and evaporated in vacuo to yield a clear glassy solid, (1.77 g, 96\%). IR (film): 2953, 2135, 1669, 1641, 1349, $1148 \mathrm{~cm}^{-1} ;{ }_{1} \mathrm{H}$ NMR (300 MHz, $\left.\mathrm{CDCl}_{3}\right): 1.18-2.46(\mathrm{~m}$, $14 \mathrm{H}), 2.62(\mathrm{t}, J 6.3,2 \mathrm{H}), 3.40(\mathrm{t}, J 6.3,4 \mathrm{H}), 3.02-3.58(\mathrm{~m}, 4 \mathrm{H}), 4.67(\mathrm{~s}, 4 \mathrm{H}), 7.23-7.28$ (m, 4H), 7.31-7.35 (m, 4H); ${ }^{13} \mathrm{C}$ NMR (75 MHz, $\mathrm{CDCl}_{3}$ ): 35-60 (multiple signals), 75.9, 122.4, 122.4, 129.6, 135.4, 135.5, 148.5, 148.5, 160.7, 187.4; LRMS (FAB) m/z (rel. intensity): 442 (35), 460 (100), 613 (15), 779 (30). HRMS (FAB): m/z calcd for $\mathrm{C}_{36} \mathrm{H}_{39} \mathrm{~N}_{6} \mathrm{O}_{6} \mathrm{~S}_{2}\left(\mathrm{M}+\mathrm{H}^{+}\right)$779.2169, found 779.218; Anal. Calcd. for $\mathrm{C}_{36} \mathrm{H}_{38} \mathrm{~N}_{6} \mathrm{~S}_{2} \mathrm{O}_{10}$ : C, 55.53; H, 4.88; N, 10.79. Found C, 50.69; H, 4.79; N, 9.20. 